SCJR 11, no. 1 (2016): 1-10

\title{
Nostra Aetate in Boston
}

\author{
JAMES M. O'TOOLE \\ james.otoole@bc.edu \\ Boston College, Chestnut Hill, MA 02467
}

Historians and theologians are just now concluding observance of the fiftieth anniversary of the Second Vatican Council. As that event begins to cross over the invisible line that separates the present from the past, it is entirely appropriate that scholars take stock of its meaning. Few would deny its significance for the Catholic Church itself, an importance that derives in part from the fact that it was a rare and unusual occurrence. When it convened in the fall of 1962, the last general council of the church had been held almost one hundred years before, and the last general council before that had been three hundred years earlier. When an event happens only a couple of times over the course of four hundred years, something big is likely to come of it.

Within the Catholic Church, Vatican II obviously had tremendous impact, initiating major changes in religious practice and also in some important understandings of theology. In practice, the changes were evident for all Catholics to see, every time they went to Mass on Sunday. The altar had been pulled away from the back wall of the church, and the priest stood behind it, facing the congregation and speaking in their own language, rather than the Latin of centuries. The people were expected to respond aloud to his invitations to prayer and, alarmingly to some, they were even expected to sing, though many stoutly resisted all encouragement that they do so. In theology, the Council brought the reformulation of some traditional concepts and understandings. Others are more qualified to speak of this than I am (I am a historian, not a theologian), but the council's adoption of the "People of God" as the governing metaphor for the church had tremendous significance. Here was a fundamentally democratic rather than hierarchical definition, a new way in which the church talked about itself. Words and images really do matter. The premier American historian of the Council, John O'Malley, S.J., has written that the real "revolution" of Vatican II was as much rhetorical as anything else. The pastoral language of the Council's documents and their "soft" style conveyed deep meaning. The use of "horizontalwords," of "humility-words," of "interiority-words"- here was the key to grasping the real meaning of the gathering for Catholics. ${ }^{1}$

In defining the relationship of the church with other religions, particularly non-Christian religions, the crucial document of the Council was Nostra Aetate,

${ }^{1}$ For this, see John O'Malley, What Happened at Vatican II (Cambridge, MA: Belknap Press, 2008), 43-52. 
promulgated at the end of the sessions in 1965. Together with its companion document on religious liberty (Dignitatis Humanae, also 1965), Nostra Aetate initiated a change that was truly revolutionary. That well-known theologian, Lenny Bruce, once supposedly said that the Catholic Church was the only "The" church; if so, the quip was not so true after Vatican II as before. In particular, the relationship between Catholics and Jews entered a new era, one that is still unfolding and will continue to do so in the years ahead. These developments played out on national and international levels. But just as important they played out on countless local levels as well, involving communities and people who could know and talk and work with one another face to face. The metaphor I always use for this kind of development after Vatican II is that of "warming air." What follows is a sketch of what happened in that warming air in greater Boston, and specifically at Boston College.

Traditionally, the Catholics and Jews of the Boston area had led largely separate lives. ${ }^{2}$ Numerically, the Catholics were much larger, constituting three of every five residents by the time of the Second World War. There was a kind of de facto residential segregation between the two groups, not enforced by law but still producing distinct communities. Where Jews and Catholics lived in close proximity - the West End neighborhood of the city, for example-there was often tension, though Jews generally addressed the problem by moving up and out to somewhere in the suburbs. Still, there were tensions, and contacts between the two groups were not always happy. We should not paint a picture of constant hostility or open warfare, but neither should we gloss over conflict. Catholic boys did indeed sometimes pick on their Jewish schoolmates, who had to find ways to avoid confrontation. The most famous example of this, perhaps, is the story Nat Hentoff tells in his memoir of almost getting beaten up one day by a group of Catholic kids. He was able to avoid his fate by convincing his tormentors that he was not Jewish but rather Greek, convincing them by reciting some lines from Homer that he was studying at the Boston Latin School. ${ }^{3}$

In the 1930s, the sharpest source of conflict between Catholics and Jews came with the prominence of the famous radio preacher, Charles Coughlin. A Canadian by birth, Coughlin was the pastor of the Shrine of the Little Flower in the Detroit suburbs, and in 1926 he had begun broadcasting sermons on Sunday afternoons over the still-new medium of radio. Everyone agreed that he had a perfect voice for radio: round, deep, melodious. At first purely devotional, he quickly took on issues of politics and the economy after the Depression set in. He started as a strong backer of Franklin Roosevelt and the policies of the New Deal but then turned violently against him. In the process, as was frequently the case, it did not take him long to get around to blaming Jews for the nation's and the world's

\footnotetext{
${ }^{2}$ For general studies, see Jonathan D. Sarna, Ellen Smith, and Scott-Martin Kosofsky, eds., The Jews of Boston, $2^{\text {nd }}$ edition (New Haven: Yale University Press, 2005), and Thomas H. O'Connor, Boston Catholics: A History of the Church and Its People (Boston: Northeastern University Press, 1998).

${ }^{3}$ Nat Hentoff, Boston Boy (New York: Knopf, 1986), 16-17.
} 
economic woes. Well-worn clichés about an "international conspiracy of Jewish bankers" became his recurring theme. ${ }^{4}$

Coughlin was tremendously popular in Boston. The corrupt but astute politico James Michael Curley (at the time, serving in his only term as governor of Massachusetts) called Boston the most Coughlinite city in the country, and no one seemed able to prove him wrong. It was said that one could walk down the street on Sunday afternoon and hear Coughlin's voice in the very air. Every radio was tuned in, and his voice just came from everywhere. Coughlin visited Boston in the summer of 1935, and politicians (including Curley) tripped over one another to get their pictures taken with him. ${ }^{5}$ There is no doubt that the preacher was popular with Boston's Catholics.

But not, significantly, with Cardinal William O'Connell, the archbishop and leader of the Catholic community in the city and throughout New England. O'Connell was one of the first American bishops to denounce Coughlin publicly, and he did so repeatedly. In 1933, speaking to a Catholic charitable group, he warned people not to be "swept off your feet by mere oratory," adding that "mere harangue" produced little improvement in social conditions. "Hysterical addresses" by priests had no place in public discourse. A year later, during ceremonies (held in Fenway Park) that honored the fiftieth anniversary of O'Connell's ordination as a priest, he took on Coughlin's anti-semitic "harangues" more pointedly. Leaders of the local Jewish community prominently shared the stage that day, this in a time when any sort of interfaith dialog was rare. In his remarks, the cardinal acknowledged them as his friends, insisting that Catholics should "never forget" their own historic connection to the Jewish people. "As Christians, we would be unfaithful to our own profession of faith," he continued, "unless we love our neighbors." O'Connell never mentioned Coughlin by name, but the newspapers pointed out that everyone knew he was talking about the radio preacher. ${ }^{6}$ The problem was that O'Connell could do nothing about him. As a priest, Coughlin was subject to the authority of the bishop of Detroit, who tolerated him longer than he should have; not until 1942, after American entry into the war, was he taken off the air. Before that, O'Connell might have tried to order his parishioners not to tune in, but they probably would not have obeyed. In the meanwhile, he made his own opinions clear, even if only by indirection.

A second episode of overt tension between Boston's Catholics and Jews came in the late 1940s and early 1950s, and it centered around a Jesuit priest

\footnotetext{
${ }^{4}$ On Coughlin's career, see Charles J. Tull, Father Coughlin and the New Deal (Syracuse: Syracuse University Press, 1965) and Alan Brinkley, Voices of Protest: Huey Long, Father Coughlin, and the Great Depression (New York: Vintage Books, 1983).

5 “Visit Social, Says Fr. Coughlin,” Boston Globe, August 13, 1935.

${ }^{6}$ For O'Connell's denunciations, see "Clerical Hysteria Hit by Cardinal; He Criticized Fr. Coughlin Without Identifying Him," Boston Globe, December 11, 1933; "Jubilee Mass for Cardinal Brings 40,000 to Honor Prelate in Fenway Park Service," ibid., June 11, 1934; "Cardinal Raps False Leaders; ... No Doubt He Refers to Fr. Coughlin," ibid., May 24, 1935. For more on these episodes, see James M. O'Toole, Militant and Triumphant: William Henry O'Connell and the Catholic Church in Boston, 1859-1944 (Notre Dame, IN: University of Notre Dame Press, 1992), 137-138.
} 
named Leonard Feeney. He was from a large, devout Catholic family; two of his brothers also became priests, and one of his sisters became a nun. He joined the Society of Jesus after graduation from high school, and he later taught some at Boston College, mostly in the summer school rather than as a regular member of the faculty. He was best known as a popular poet and essayist, serving as literary editor of America magazine, the Jesuits' biweekly. He was a skilled preacher with a gift for mimicry: when he delivered sermons in the voices of such celebrities as Katherine Hepburn and Harry Truman, there were always cries for encores. After the end of the war, he became associated with the Saint Benedict Center in Cambridge, a storefront meeting place for Catholic students at Harvard, Radcliffe, and other colleges in the area. Feeney was the main attraction, and many students were drawn to the Center, they said, because of the impact of the dropping of the atomic bomb. The prospect of the obliteration of all life on earth had prompted many spiritual crises, sending students flocking to the Center, which produced several Catholic converts, most prominently Avery Dulles, later a renowned theologian and cardinal. ${ }^{7}$

After some calm early years, Feeney and his followers began to develop extreme theological positions, centering particularly on the doctrine, extra ecclesiasm nulla salus - "outside the church, there is no salvation." This idea had a very long pedigree, first articulated in the third century in the contest between Christianity and paganism. In its strictest interpretation, it could be taken to mean that all non-Catholics were going to hell by definition, and this was the view that Feeney and his followers insisted on, even as the church itself was moving to a more conciliatory understanding. Especially given the aggressively anti-semitic turn that Feeney subsequently took, it is important to note that, at the outset, his real targets were other Catholics whom he judged to be insufficiently rigorous on this and other points. Catholics were too eager to abandon the doctrine, however harsh, he thought. In hopes of winning approval from their Protestant "betters," they had watered down their faith. "The American Catholic is a sort of diluted Catholic," one Center partisan wrote, and Boston Catholics may have been the soggiest of all. Why, even Jesuits were studying at Harvard, she pointed out, and little good could come of that. Feeney's initial targets were these supposed weakkneed Catholic fifth columnists. ${ }^{8}$

Concern for diluted Catholics led to a particular concern for diluted Catholic education, particularly the kind of Catholic higher education available at Boston College. Several lay members of the faculty were frequenting the Center, absorbing its outlook. In the process, they missed what others saw: that the place was spinning out of control. Simply put, Feeney had gone crazy, and he was taking

\footnotetext{
${ }^{7}$ Avery Dulles, "Leonard Feeney: In Memoriam," America (February 25, 1978): 135-137, recalls the early days of the Saint Benedict Center.

${ }^{8}$ See Catherine Goddard Clarke, The Loyolas and the Cabots: The Story of the Boston Heresy Case (Boston: Ravengate Press, 1950) for the extended critique of "diluted" Catholics. Clarke was cofounder of the Saint Benedict Center and Feeney's closest aide.
} 
other people with him. Consider the evidence from no less an observer than the British novelist, Evelyn Waugh. He visited the Center in 1948, while in America on a lecture tour, and he described the episode in a letter to his wife back home in England. "I went one morning by appointment, and found [Feeney] surrounded by a court of bemused youths of both sexes - and he stark raving mad." The priest delivered a long, rambling diatribe against a list of Catholic theologians and writers, prompting a sharp retort from the ardently Catholic Waugh. The crowd was "aghast," he said, at hearing their "holy man" addressed in such a way. Waugh left the premises, uncertain whether Feeney's problem was psychological, or something worse: "a case of demonic possession," he concluded, perhaps not meaning it as a joke, "and jolly frightening." 9

Three young lay members of the Boston College faculty had a different opinion, and they began introducing Feeney's ideas into their own classes. Since they taught courses in the philosophy of science, in math, and in physics, however, the subject was entirely extraneous: the question of who went to heaven and who did not had nothing to do with physics and even less with math. College administrators told them to keep their theological views out of their classrooms, but they refused, ratcheting up their denunciations of the college as promoting heresy. Again ordered to stop, they refused, and in the spring of 1949, in the middle of the term, they were fired; a cohort who was teaching German at Boston College High School was dismissed for the same reason. Public demonstrations by supporters of the Saint Benedict Center followed, including the picketing of local Catholic churches on Easter Sunday. Archbishop Cushing, who had succeeded Cardinal O'Connell, forbade Catholics from frequenting the Center, and Feeney was dismissed from the Jesuit order; two years later, he and his followers were officially excommunicated - an ironic ending, to say the least, for those who had preached that there was no salvation outside the church. They themselves were now outside it. They continued in the public eye, however, holding open air rallies on the Boston Common. It was at this point that the target shifted, and Feeney turned in a blatantly anti-semitic direction. Eventually, he and his followers withdrew to a farm in central Massachusetts, where they organized their own selfidentified religious order. But the turmoil did not cease: they subsequently splintered into about six warring factions before Feeney's death in $1978 .^{10}$

This was obviously a sad and painful episode in Boston history generally and in the history of Boston's Catholics and Jews in particular. We should not diminish its impact. Feeney's "problem" with Jews (or with anybody else) was neither theological nor sociological; it was clinical. He was indeed mad. But the lasting

\footnotetext{
${ }^{9}$ Evelyn Waugh to Laura Waugh, November 20, 1948, Letters of Evelyn Waugh, ed. Mark Amory (New York: Penguin, 1980), 291-293.

10 "Fr. Feeney, Priest in Heresy Case, Dies," Boston Globe, January 31, 1978; also see Mark S. Massa, Catholics and American Culture: Fulton Sheen, Dorothy Day, and the Notre Dame Football Team (New York: Herder and Herder, 1999), ch. 1, and Mark Silk, Spiritual Politics: Religion and America since World War II (New York: Simon and Schuster, 1988). For the later history see Gabriel Gibbs and Owen J. Murphy, Harvard to Harvard: The Story of Saint Benedict Center's Becoming Saint Benedict Abbey (Still River, MA: Ravengate Press, 2006).
} 
significance of the entire episode may have been that it brought to prominence a new leader for Boston's Catholics, Richard Cushing, and he was able to turn things in a new direction.

Richard James Cushing was born in South Boston in 1895, the son of immigrant parents. Like most Catholic priests of his era, he was a child of the working class. He would observe that, in the 1950s, there was no Catholic bishop in America whose parents had gone to college-perhaps not technically accurate, but true enough to highlight the long connection of the church to those on the lower rungs of the social and economic ladder. Young Richard had enrolled at Boston College in 1913 and, as was common then for those intending a career in the priesthood, he left at the end of his sophomore year to enter Saint John's Seminary in Brighton, located just across the street from the college campus. He was ordained a priest in 1921 and, instead of a regular parish assignment, he was put in charge of the archdiocesan office that supported the work of foreign missions. This gave him a broad vision of the role of the church in the world while, more practically, cementing his reputation as a prodigious fund-raiser. In 1944, when Cardinal O'Connell died, Cushing was named his successor as archbishop for Boston's Catholics; he was made a cardinal in 1958 and served until his death in 1970. ${ }^{11}$

This was a time of tremendous change in greater Boston. The population of the city itself was declining at an alarming rate. In the 1950s, Boston lost 100,000 residents (from a high of 800,000), while nearby suburbs such as Canton and Framingham doubled in size, practically overnight. To address these shifts in the population, Cushing presided over a rapid expansion of the local Catholic infrastructure. There were about three hundred parish churches at the beginning of his tenure, more than four hundred at his death twenty-five years later. Churchrelated schools, hospitals, and social service agencies similarly expanded. Amid this growth and development of his own flock, Cushing also reached out to the leaders of other faiths and sought opportunities for cooperative ventures. This was new. In Boston as elsewhere around the country, religious leaders of all denominations kept mostly to themselves; joint appearances, even on purely civic occasions, were rare. By Cushing's time, this was beginning to change, and he seemed to relish the development. When the evangelist Billy Graham came to Boston for one of his two-week crusades in 1964, for instance, the two spent a laugh-filled afternoon together, smiling broadly in the pages of the newspapers. ${ }^{12}$

Cushing's particular role in improving relations between Catholics and Jews was crucial, and it played out both locally and on a larger stage. One of his brothers-in-law was Jewish, and this may have added a personal dimension to his efforts to bring the two communities together. He took every occasion to be seen publicly working to overcome the divisions of the past. In 1948, for instance, he addressed the fifteen hundred delegates to the convention of the Union of Hebrew Congregations, meeting in Boston. When he learned of episodes of Catholic boys beating up Jewish kids (those not as clever as Nat Hentoff), he would send local

\footnotetext{
${ }^{11}$ For Cushing and his tenure, see O'Connor, Boston Catholics, ch. 7.

${ }^{12}$ See, for example, “'I Trust in the Lord,"” Boston Globe, October 8, 1964.
} 
parish priests to visit the homes of the aggressors, making clear the parents' responsibility to curb such activity. His ongoing effort to silence Father Feeney was the most visible example of his stance against anti-semitism. But on a larger stage, he played a small but significant role in shaping the Vatican II documents that changed the church's official approach to these issues. ${ }^{13}$

He attended the sessions of the Council, which were held in the fall of every year between 1962 and 1965. He told reporters that he found it difficult to follow what was going on because the debates were conducted in Latin and his facility in that language was marginal; he attempted to speak in French once and was corrected by an Italian cardinal. (It was reported that he offered to pay for simultaneous translation, but this was not done.) As a result, he did not take an active role in the debates, though when he did it was to good effect. His wellknown friendship with the Kennedy family, both before and after the president's assassination, made him instantly recognizable to bishops from around the world, and they paid special attention to what he said for that reason. He addressed the assembly for the first time in September 1964 during the debate over the text of Dignitatis Humanae, the document that endorsed the idea of religious liberty for all. Speaking, he said, on behalf of "almost all the bishops of the United States," he said that the time had come for the Catholic Church to show itself as supporting the same kind of liberty for others that it had always sought for itself - "civil liberty, especially in the matter of religion." In effect, the days of the "The Church" were over. It would take another year before the final text of the document, embodying these principles, was completed and finalized, but his comments had marked a turning point. ${ }^{14}$

He made a similarly effective intervention in the debate over Nostra Aetate. When its text came up for discussion a week after his first address, he again took the floor and urged the Council to make a clear statement - and not, he said, a "timid" one - on the connections between Christians and Jews. The Church had to "manifest to the whole world and to all men a concern which is genuine, an esteem all embracing, a sincere charity" in its relationship to the Jewish community. Jews were, after all, the "blood brothers of Christ." He wanted an explicit rejection of the idea that Jews had been responsible in a particular way for the death of Jesus, and he called for an acknowledgement that Christians had not always lived up to their responsibilities to respect and work with their Jewish neighbors. He spoke so personally that, in violation of the rules of the Council, the other bishops in attendance applauded. Here again, drafting the final version of the text took another year, but when it was officially published in October 1965, it bore the mark of his effort, speaking of "the spiritual patrimony common to Christians and Jews" and saying that "the Church rejects, as foreign to the mind of Christ, any

\footnotetext{
${ }^{13}$ O'Connor, Boston Catholics, 256-259.

${ }^{14}$ Cushing's remarks are quoted ibid, 264. For the larger debate over the document, see O'Malley, What Happened at Vatican II, 241-243 and 287-288.
} 
discrimination of men or harassment of them because of their race, color, condition of life, or religion." 15

The impact of these and other Council documents was swift and, as I suggested at the outset, it was an impact that was felt locally as well as internationally. I offer a brief example of the fundamental changes that Vatican II wrought on a single American college campus, that of Boston College. The school had been founded by Jesuit priests in 1863 to provide education for the sons of Irish and other Catholic immigrants who had begun to flood into the city. Some of the early students were immigrants themselves, though most were the sons (not yet the daughters) of those who had come to America seeking a better life. The school was located in the South End neighborhood of the city, a district with an overwhelmingly immigrant population, and the first students were admitted in the fall of 1864. Twenty-two showed up on the first day, the first dean saying of them that "only one or two had talent." Though called a "college," the institution in its earliest days was in fact more of a middle or high school; the average age of the students in the first decades was sixteen or less. The goal was to provide education beyond the basic level of the Three R's as a way of offering a step up into the professions for the second and third generations of families. The curriculum had a heavy emphasis on Latin, Greek, and philosophy, spread out in a program that (if pursued completely) might take seven years. This prompted a public dispute in the 1890 s when Harvard announced that it would no longer admit Boston College students to its law school on the grounds that a Boston College degree was not a "real" academic degree. The Jesuits rose to the defense of their school and got the ban reversed, but they also recognized that Harvard was, to a significant degree, right and that their curriculum had to change. This led to a clear separation of Boston College and Boston College High School, and it also brought a relocation of the collegiate division to a new campus in Chestnut Hill, a district that straddled the line between Boston and the suburban city of Newton. $^{16}$

The student body had been primarily Catholic from the beginning, though the college charter expressly prohibited any discrimination in admissions on account of religion or race. A handful of non-Catholic students enrolled in the nineteenth century-they were exempt from taking the religion classes that their Catholic schoolmates took - and this continued into the twentieth. Over time, the institution took some halting steps toward broadening its student body. The first Jewish students I have been able to identify were members of the class of 1935: Milton Borenstein and Milton Cohen. Borenstein was from Everett, wrote for the student newspaper, and was a star member of the debating team; after graduation he went

\footnotetext{
${ }^{15}$ Again, see O'Connor, Boston Catholics, 264-265, for Cushing's role in the debates. For the text of Nostra Aetate, see The Documents of Vatican II, ed. Walter Abbott (New York: Guild Press, 1966), 660-668. Dignitatis Huamae is ibid., 675-696.

${ }^{16}$ The most complete account of the early years is in David R. Dunigan, A History of Boston College (Milwaukee: Bruce, 1947). For the dispute with Harvard, see Kathleen A. Mahoney, Catholic Higher Education in Protestant America: The Jesuits and Harvard in the Age of the University (Baltimore: Johns Hopkins University Press, 2003).
} 
to law school, practiced law, and then managed a family business. Cohen was from Brookline, a pre-med student who became a doctor, spending most of his career on the staff of the Carney Hospital in Dorchester. They were Jewish, not Catholic, but they were otherwise very much like their fellow students: secondgeneration kids seeking an education so as to advance the fortunes of their families over the decades. With a further nationalization of the student body, starting in the 1950s - and especially with the decision in 1970 to become fully coeducational-greater racial, ethnic, and religious diversity became the norm at Boston College. By the early 1970s, what was then called the Black Talent Program had been initiated for African American students, and at the same time a Jewish Student Alliance was formed. This became formally affiliated with Hillel, the national organization for Jewish college students, in $1976 .{ }^{17}$

More significant, perhaps, as a direct impact of the work of Vatican II were changes that came to the curriculum, particularly in the study of theology. These changes were felt right away in the remaking of theology courses. The study of religion had always been an important part of the college's program: Catholic students took one such class every one of their eight semesters on campus. For the early years, however, it is not really accurate to call these theology courses as we understand that term. They were in effect catechism classes, with a clearly apologetic purpose, designed to instill in the students habits of religious practice that they would carry into adulthood; the classes were even sometimes called simply "evidences of religion." The theology faculty consisted entirely of Jesuit priests, and it was assumed both that it would always be that way and indeed that it had to be. Brief consideration was given in the 1950s to establishing a master's program in theology for lay people, but the dean and the president rejected the idea. They could not imagine that graduates of such a program would ever be able to find jobs in their field. "Would a Catholic college hire a layman" to teach theology, the president wondered aloud: it seemed unlikely. ${ }^{18}$

In the aftermath of the Council, however, the inadequacies of this approach to the discipline were immediately apparent, and the theology department moved quickly to reform itself. The speed of this effort is striking. With the opening of classes in the fall of 1966, less than a year after the final session of Vatican II, two new faculty members had joined the department, the first non-Jesuits. One was a woman: Mary Daly, a specialist in the work of Paul Tillich with a degree from Fribourg. She later became one of the founders of the new field of feminist theology and was controversial on campus for the remainder of her career. The second newly hired faculty member was perhaps even more unlikely: a rabbi, David Neiman. He had been born in Russia, immigrating to the United States with his family as a child. A biblical archaeologist who had previously taught at

\footnotetext{
${ }^{17}$ See entries in the Boston College yearbook, Sub Turri: 1935, 31 (Borenstein) and 44 (Cohen); 1972, 164 (Jewish Student Alliance); 1977, 177 (Hillel).

${ }^{18}$ For a typical listing of "Evidences of Religion" courses, see Boston College Catalog, 1920, 62. On the rejection of a master's program, see Michael Walsh to Richard Rousseau, October 7, 1959, Walsh Papers, Box 8, Folder 12, University Archives, Boston College.
} 
the New School in New York and at Brandeis, on coming to Boston College he became the first theology professor with a regular appointment at any Catholic university in America who was Jewish. He taught courses in Hebrew literature and thought, including a perennially popular course on the Book of Genesis. He remained an active force in the ongoing reform of the theology curriculum until his retirement in 1991; he died in 2004. ${ }^{19}$

Little of this would have been possible without the changes that came with Vatican II in the relations between Catholics and Jews, locally and more widely. Those changes have continued in the half century since the promulgation of Nostra Aetate. The dialog and mutual respect that it helped initiate continue, and if that dialog is to be fruitful, it must be grounded on an understanding of where we have come from. We must look at both the bad and the good dimensions of that history if we are to understand it and move forward. The future can never be predicted, of course, and to a greater or lesser degree it always surprises us. But the foundations that the Council laid are firm and will provide the basis for ongoing conversations. That surely gives us something to celebrate.

${ }^{19}$ On the unusual appointments, see "2 Theologians Named at B.C.," Boston Globe, May 14, 1966. 